\title{
ARTIFICIAL NEURAL NETWORKS OF TECHNICAL STATE PREDICTION OF GAS COMPRESSOR UNITS ELECTRIC MOTORS
}

\author{
O.V. Kryukov', o.kryukov@ggc.nnov.ru, \\ A.V. Serebryakov', serebryakov@ardman.ru \\ ${ }^{1}$ Giprogazcenter JSC, Nizhny Novgorod, Russian Federation, \\ ${ }^{2}$ Nizhny Novgorod State Technical University n.a. R.E. Alexeev, Nizhny Novgorod, \\ Russian Federation
}

\begin{abstract}
Issues of engineering effective and reliable systems for on-line diagnostics of electric motors of electrically driven compressor stations are considered. The paper provides failure statistics for the most critical gastransport systems' units - electrically driven gas-compressor stations. Artificial neural networks methodology and architecture were developed to obtain prediction models of MW electric machines. Examples of neurofuzzy prediction of synchronous machines stator winding performance and service life are given. Selected network tests, the Box-Jenkins fuzzy model, models of the analysis technique of spectral components dynamics, current magnitude and stator temperature prediction are received. Based on results of comparative analysis of anticipated conditions of electric machines for main gas transport with due regard to various operational factors of electrically driven gas-compressor units, recommendations on application of the artificial neural network method have been drawn up.

Keywords: electrically driven compressor stations, gas compressor station, $M W$ electric motors, artificial neural networks, selected networks tests, prediction models of current magnitude and stator temperature.
\end{abstract}

\section{Introduction}

Nowadays, all process units of the main gas pipeline compressor stations (CS) are classified as hazardous industrial facilities [1-5]; therefore, the development of reliable and operative monitoring systems of their performance is a task of the first priority at gas transport systems designing. Up-to-date electrically driven gas compressor units (EGCU) as diagnostic objects represent complicated and space-distributed engineering systems with heterogeneous elements [4-7]. A great number of methods of evaluation and prediction of their technical condition is used for their state identification [8-12].

Statistical data on more than 100 EGCU failure events at $6 \mathrm{CS}$ of Gazprom JSC have demonstrated that recovery after the failure of electric drive motor and especially stator fault is the most cost- and timeconsuming [13-17].

Main operational factors of 60 STD-12500-2 and SDG-12500 electric motors were measured in different modes under conditions of operating compressor shops to reveal the most typical damage types. A complex analysis helped to determine 4 groups of operational factors [14-18] having an influence on EGCU electric motors lifetime: heating insulation of the stator winding, variation of supply voltage parameters, electrodynamic loads in rods and partial discharges in the winding insulation.

\section{Methodology of EGCU technical state neural networks}

The most efficient method of monitoring and prediction of EGCU technical state as well as other electromechanical systems with MW machines is the well-approved mathematical tool of automated setting parameters of the diagnostic algorithms based on the artificial neural networks (ANN) aggregated in the decision-making system (DMS) for identification of different defects [19-23].

The ANN's enable an independent solving the problems of classification of item variables and their forms as well as self-learning using the predictive algorithms based on previously registered failures. The ANN allows developing a nonparametric model that can reproduce any operative/fault state of the EGCU and approximate its identification.

This model is capable to store examples of events, allocate significance of structure connections on their basis and eliminate neurons or connections that do not influence storing these examples.

The architecture of the in-built monitoring and prediction systems (IBMPS) of EGCU technical condition in ANN represents two subsystems:

- a subsystem of data reception and processing that corresponds to IBMPS of EGCU STD-12500-2 operation with receiving data on technical condition of the drive high-voltage synchronous motor (DHVSM) and its further processing (data distribution and valuation of variables);

- a subsystem of interpretation of the received data on technical condition with the use of ANN failure-recognition algorithms and recommendations on its further actions realization (Fig. 1).

DHVSM ANN construction sequence. Application of a great number of DHVSM controllable variables (voltage, currents, partial discharges and stator winding temperatures) at EGCU technical condition prediction allows improving accuracy and efficiency 


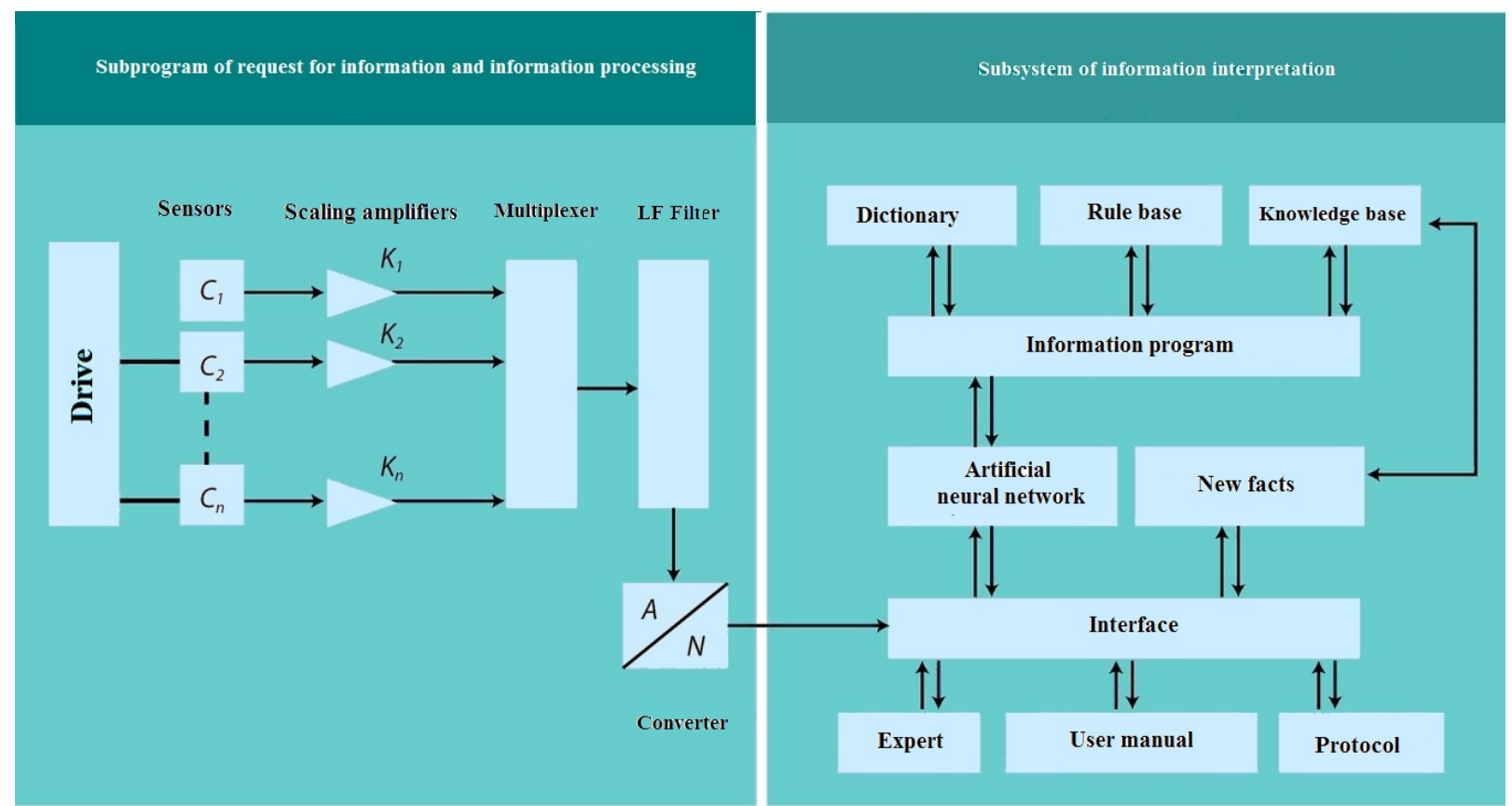

Fig. 1. Architecture of automated ANN of EGCU DHVSM

of monitoring procedure. At the first stage of the ANN module realization, its dimensions, that is, the number of its inputs and outputs shall be specified (it is reasonable to take these values as equal to 3 and 1).

Then, the network architecture is designed based on the learning algorithm and minimization of the root-mean-square error of monitoring results and prediction prospects of DHVSM technical condition with determination of residual life.

Before embedding the ANN unit (Fig. 1) into the subsystem of information interpretation within the IBMPS structure, it is necessary to examine the functioning of three ANNs with inputs of different architecture. At this, the inputs of these three ANNs are not of the same size, therefore, their structures selected after the learning phase will differ and have a different number of internal layers and neurons in these layers. After the most reasonable network of DHVSM technical condition based on volumetric parametric study of the three ANNs has been selected, the following four decisions are required.

1. Final choice of diagnosed variables. Copper temperature, intensity of partial discharges and overvoltage level of supply mains are the most informative input variables describing technical condition of insulation of the STD-12500-2 stator winding. In-situ experimental research has demonstrated at different compressor stations (CS) that an adequate assessment of technical condition and prediction of abnormal modes are possible exactly with these parameters. Besides, these variables are available for direct measurement by standard facilities and their direct entry in the neural knowledge base (NKB). The papers [1-3, 24-28] represent results of measurements of these operational factors and general statistics of observations for the period since 1985 till 2010 with recorded 62 events of STD-12500-2 failures.

2. NKB design. The ANN-based model describing operative and fault states of EGCU DHVSM stator winding requires an optimal NKB design with a sufficient information on possible troubles occurring in various EGCU-12.5 modes. Based on existing failure statistics (and probable trouble simulations) of STD-12500-2 machine, all failures are divided into 12 types (including serviceable conditions); current variations of three previously selected input variables are assessed for each state during the whole period of measurements. As a result, the NKB for each variable amounted 3,000 different values (vectors) describing possible electric motor's modes of operation. This value corresponding to the measurement number and results of the experiments carried out shall be entered into the ANN structure (Table 1).

3. ANN block creation. Determined neural networks are multilevel ones with an optimal selflearning algorithm. To integrate the ANN block into the DHVSM IBMPS, three neural networks may be studied. After they have been tested and compared with each other, the most eligible one for solution of the whole complex of ANN prediction tasks may be chosen. At this, neural networks engineering and feasibility stages are divided into three phases (Fig. 2). The first one is connected with the choice of inputs and NKB design premised on the files obtained during the analysis of three above monitoring parameters. The second one is associated with the choice of networks outputs (for each separately) and their codes, and the third - with the choice of network architectures. 
NKB structure on ANN basis

\begin{tabular}{|l|c|c|}
\hline \multicolumn{1}{|c|}{ Stator winding failure type } & Symbol & ANN code \\
\hline Overheating in bore slotted area & & 000000000001 \\
\hline Overheating at end winding & & 000000000010 \\
\hline Overheating at leads & & 000000000100 \\
\hline Overheating during unit startup & & 000000001000 \\
\hline Hold-off overvoltage & & 000000010000 \\
\hline Overvoltage at contact chatter & & 000000100000 \\
\hline Overvoltage at single phase earth fault & & 000001000000 \\
\hline Overvoltage at turn-to-turn short circuit & & 000010000000 \\
\hline Contamination with oil and graphite mixture & & 000100000000 \\
\hline Insulation fault in slotted area & & 001000000000 \\
\hline Insulation fault at end winding & QN & 010000000000 \\
\hline Absence of insulation faults features & & 100000000000 \\
\hline
\end{tabular}

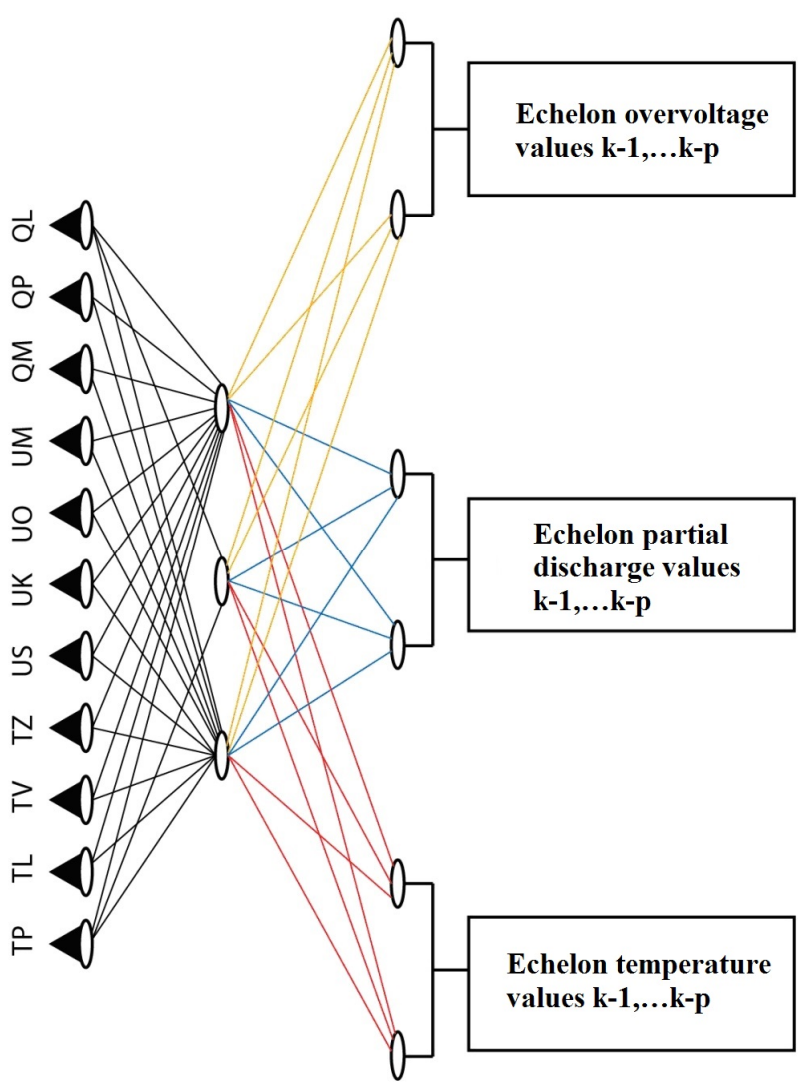

Fig. 2. Structure of the third ANN

4. Determination of selected networks tests. At number of used ANN block inputs equal to ten (in fig. $2-p=10$ ), table 2 gives test results according to [1-3] for each controllable variable.

For the three networks, the stage of selecting is carried out when testing the second network ends after 148 presentations of each example. At that, the testing is carried out in two stages: at first one the network performs 100 repeated studies for each failure condition, at the second - they are re-entered into the test program that terminates after 48 iterations with a root-mean-square error of the testing results equal to $3.7 \mathrm{Ve}^{-16}$ (Fig. 3).
Testing neuron networks. After three neuron networks have been generated and the desired accurate indices at their learning have been achieved, their complex comparison becomes the most important stage. At that, the comparison is performed by testing each ANN input and output. This procedure is associated with the learning stage and determination of the base for testing ANN ability to detect hidden defects that previously were not considered at the EGCU performance evaluation, and its ability to generalize results.

So, IBMPS of technical condition of DHVSM of STD-12500-2 type provided for selection of the best of three ANNs (Fig. 2) by their testing for the abovementioned defects (Table 1). It enabled their 
Root-mean-square error Zero signal zone

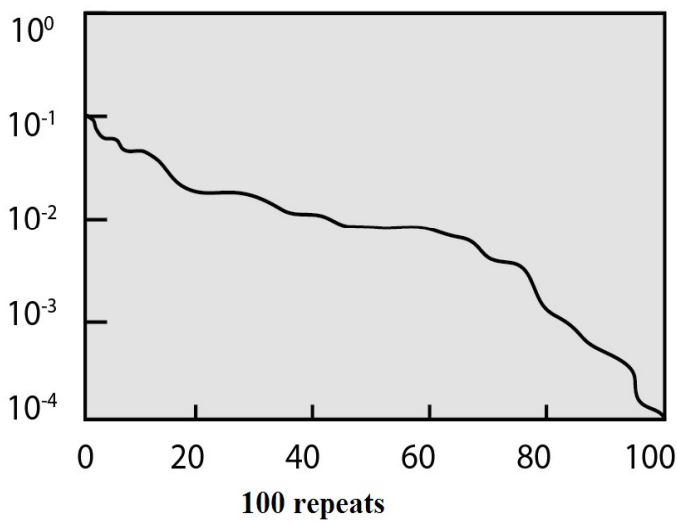

a)

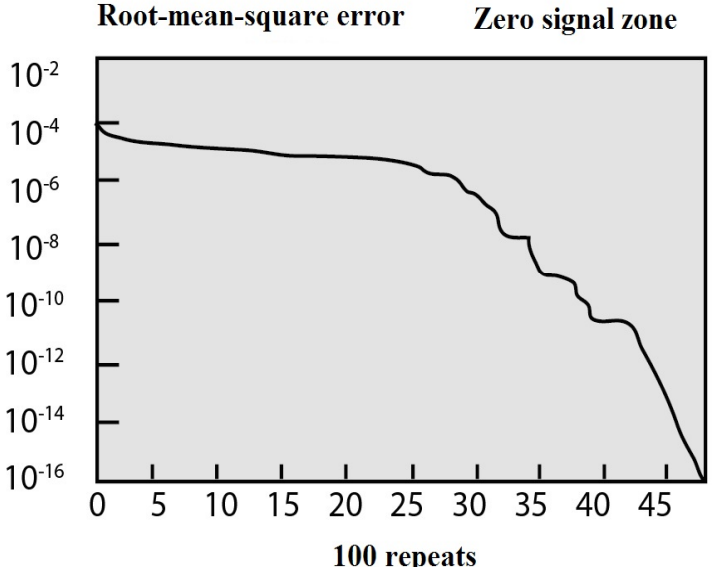

b)

Fig. 3. Root-mean-square error evolution for ANN

identification with high precision; that is proved by the values of diagnosis root-mean-square errors close to zero (Table 2). The third network was tested for STD-125000-2 failures studied at the network learning phase, results of its simulation to reveal faults associated with overheating in bore slotted area are given in table 3 .

The outputs of the third network are given here under various relative loads of mechanical components of the electric motor. The first line of table 3 corresponds to the defect considered at this test phase, i.e. at overheating the STD-12500-2 stator winding insulation in its bore middle part. This defect was detected almost by $100 \%$ for the most EGCU modes. ANN input variables test results do not differ distinctly for other modes. Therefore, for example, the minimum value of test results corresponding to the considered defect was equal to 0.857 ; that is, close to manifestation of the same defect in the mode of $40 \%$ of DHVSM rated load.

The analysis of results obtained at test phase of all three ANNs revealed that the third neuron network (see Tables 2 and 3) is the most efficient and therefore may be reasonably used in the EGCU IBMPS. The third network outputs that are close to the desired value should be approximated to zero or to one to provide reliability of identification of failures in the DHVSM stator insulation with indication of their source and location. At that, the substantiation of objective recommendations for elimination of similar problems is the principal result of IBMPS operation on the ANN base.

\section{Comparison of EGCU technical condition prediction results}

For comparison of prediction results' validity for forecasting EGCU DHVSM technical condition with different methods, we will consider the trend describing daily variations of STD-12500-2 stator temperature during EGCU operation (Fig. 4, a curve) and make performance analysis of inertial prognostic methods. For this purpose, we will divide the known time series describing temperature variation into two parts; first of them will be the basis for prediction and the second one - for checking a posteriori precision of prediction.

Application of the methods based on fuzzy ARMA-models (particularly, Box-Jenkins method) [1] is possible as the numerical series of ordinary differences of temperature time series is stationary. As follows from the diagram in Fig. 4, methods based on the Box-Jenkins models make a very optimistic prognosis with an increasing trend ( $c$ curve). Obtained data cannot help to determine the moment of temperature values going beyond the permissible limits authenti-

Testing results for three ANN

Table 2

\begin{tabular}{|c|c|c|c|c|}
\hline \multirow{2}{*}{$\begin{array}{c}\text { ANN } \\
\text { No }\end{array}$} & \multicolumn{4}{|c|}{ Number of neurons } \\
\cline { 2 - 5 } & $\begin{array}{c}\text { Input } \\
\text { layer }\end{array}$ & $\begin{array}{c}\text { Internal } \\
\text { layer }\end{array}$ & $\begin{array}{c}\text { Output } \\
\text { layer }\end{array}$ & $\begin{array}{c}\text { Root-mean- } \\
\text { square error }\end{array}$ \\
\hline 1 & 10 & 13 & 11 & $3.24221 \mathrm{e}^{-15}$ \\
\hline 2 & 20 & 8 & 11 & $3.71314 \mathrm{e}^{-16}$ \\
\hline 3 & 30 & 6 & 11 & $3.26580 \mathrm{e}^{-17}$ \\
\hline
\end{tabular}

Test results of the third ANN

Table 3

\begin{tabular}{|c|c|c|c|c|c|c|}
\hline ANN & \multicolumn{7}{|c|}{ Load, \% of nominal } \\
\cline { 2 - 7 } outputs & $90 \%$ & $80 \%$ & $60 \%$ & $40 \%$ & $20 \%$ & $10 \%$ \\
\hline 1 & 1,0000 & 1,0000 & 1,0000 & 0,8570 & 1,0000 & 0,9605 \\
\hline 2 & 0,0000 & 0,0000 & 0,0000 & 0,0000 & 0,0000 & 0,0005 \\
\hline 3 & 0,0000 & 0,0000 & 0,0002 & 0,0000 & 0,0000 & 0,0034 \\
\hline 4 & 0,0049 & 0,0000 & 0,0000 & 0,0000 & 0,0000 & 0,0000 \\
\hline 5 & 0,0000 & 0,0000 & 0,0000 & 0,0000 & 0,0000 & 0,0000 \\
\hline 6 & 0,0000 & 0,0000 & 0,0000 & 0,0000 & 0,0000 & 0,0000 \\
\hline 7 & 0,0000 & 0,0000 & 0,0000 & 0,0057 & 0,0000 & 0,0000 \\
\hline 8 & 0,2310 & 0,0000 & 0,0067 & 0,0000 & 0,0000 & 0,0000 \\
\hline 9 & 0,0000 & 0,0000 & 0,0000 & 0,0000 & 0,0000 & 0,0000 \\
\hline 10 & 0,0000 & 0,0000 & 0,0000 & 0,0000 & 0,0000 & 0,0000 \\
\hline 11 & 0,0000 & 0,0000 & 0,0000 & 0,0000 & 0,0000 & 0,0000 \\
\hline
\end{tabular}




\section{Электромеханические системы}

cally. The value of a mean relative prediction error made up $23-58 \%(\bar{\Lambda}=0.23-0.58)$.

The above ANN-based method was also used for efficiency check. The Ward network was applied for this purpose; previous values of time series were supplied to its inputs. This type was selected because the ANNs of this type are capable to determine significance of the input values. The modelling has demonstrated that the developed and learnt ANN allows determining a general tendency of temperature rise at the uncertainty limit of a temperature time series but gives a pessimistic prediction ( $b$ curve). As a result, it is possible to determine the trend in process, but it is impossible to determine authentically the moment of temperature values going beyond the permissible limits. The value of a mean relative prediction error made up $16-46 \%(\bar{\Lambda}=0.16-0.46)$.

For temperature trend prediction with the method of time series (SCDA) [4] the background of a temperature series with $N=400$ readouts was used. The obtained multi-step forecast ( $d$ curve) allows to mark out an increasing trend of the series and to de- termine the moment of temperature values going beyond the permissible limits with a high accuracy. The value of a mean relative prediction error made up $8-34 \%(\bar{\Lambda}=0.08-0.34)$.

Based on the above studies we may conclude that the time series method enables more exact predictions of temperature drift of STD-12500-2 stators in comparison with those based on predictive models and ANN.

Similar results were received at comparison of prediction of STD-12500-2 stator currents (Fig. 5) with the Box-Jenkins methods ( 8 curve) with an error of $34-127 \%$, the Ward's ANN ( 6 curve) with an error of $27-84 \%$ and the method of SCDA time series ( $d$ curve) with an error of $11-58 \%$.

However, the specificity of the EGCU operation is a slow response (time constants) including thermal conditions and partial discharge parameters changes. Therefore, a method for forecasting specific EGCU conditions may be determined based on a combination of main gas pipelines' conditions, operational modes and various system peculiarities of compressor equipment at compressor stations.

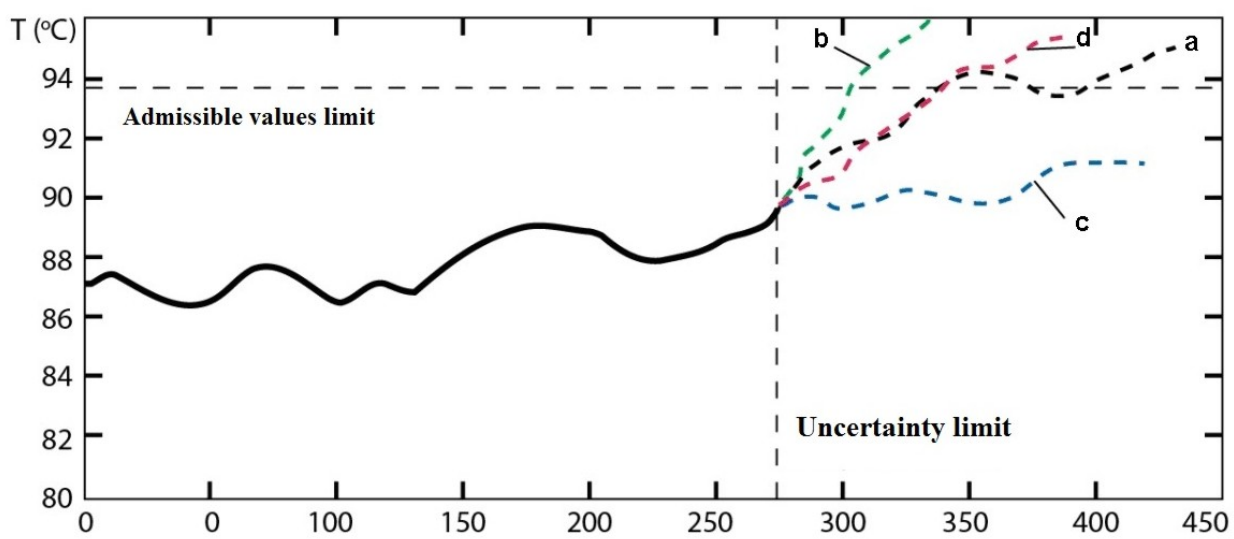

Fig. 4. STD-12500-2 electric motor stator temperature prediction: a - actual temperature series, b - prediction, received with ANN application (Ward network), c - prediction, received with BoxJenkins model application, $d$ - prediction, received with SCDA (spectral components dynamic analysis) method application

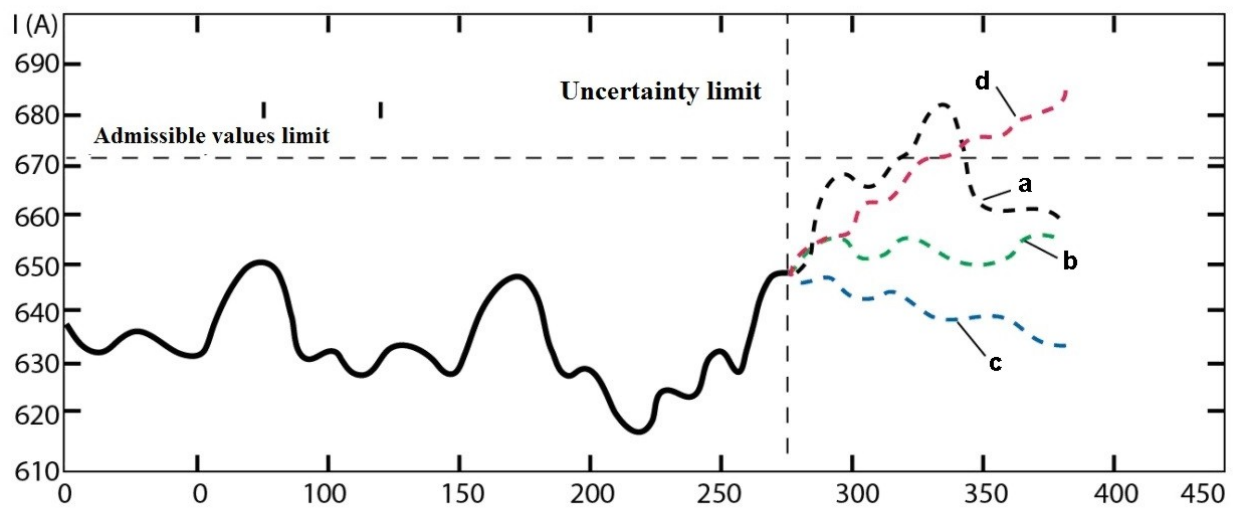

Fig. 5. Prediction of STD-12500-2 electric motor stator currents: a - actual time series, $b$ - prediction, received with ANN application (Ward), c - prediction, received with Box-Jenkins model application, $\mathrm{d}$ - prediction, received with time series method application 


\section{Conclusions}

1. The monitoring system for assessment of impact of DHVSM operational factors on stator insulation lifetime has been developed; it demonstrates that:

- The temperature of windings in motor middle part is by $23{ }^{\circ} \mathrm{C}$ higher than that in its end parts, the frequency of insulation failure makes up more than $86 \%$ here. Besides, at machine sudden shutdown the temperature increases by another $15-20{ }^{\circ} \mathrm{C}$ posing a threat of thermal shock and overheating of the windings;

- ISG-10 kV line voltage during 82 hours of observation may make up $10.37-10.91 \mathrm{kV}$, that is, exceed standard values and have considerable form distortions;

- mechanical loads are insignificant because of electrodynamic efforts in bars of stator windings even at DHVSM reactor start-up;

- All STD-12500 machines have partial discharge of different amplitude and intensity; on-line monitoring partial discharges enables an adequate assessing of DHVSM technical condition.

2. Results of estimation of the DHVSM IBMPS efficiency on the base of fuzzy logic methods (Box-Jenkins) and ANN (Ward's net) at STD-12500 engineering data prediction in cases of the developing gradual failures have demonstrated that they produce more precise results in comparison with traditional extrapolation methods and enable more adequate and timely decisions. The prediction method based on time series gives a more exact result at multistep prediction of quick current changes with absence of additional data at the stage of the model identification. However, a rational choice of a technical condition prediction method of a particular EGCU is determined by the combination of main gas pipelines' conditions, operational modes and various system peculiarities of gas compressor equipment at compressor stations.

\section{References}

1. Puzhaylo A.F. et al. Energosberezhenie $i$ avtomatizatsiya elektrooborudovaniya kompressornykh stantsiy $M G$ [Energy-Saving and Automation of GM Compressor Stations Electrical Equipment]. O.V. Kryukov (ed.). N. Novgorod, Vector TiS, 2010. 570 p.

2. Kryukov O.V. [Analysis and Engineering Feasibility of Energy Efficiency Factors of Innovation Solutions in Electrically Driven Turbo-compressors]. Avtomatizatsiya $v$ promyshlennocti [Automation in Industry], 2010, no. 10, pp. 50-53. (in Russ.)

3. Kryukov O.V., Stepanov S.E. [The Ways of Electric Driven Gas Compressor Units Modernization]. Електромеханічні і енергозберігаючі систе$м и$ [Electromechanical and Energy-Saving Systems], 2012, no. 3 (19), pp. 209-212.

4. Zakharov P.A., Kiyanov N.V., Kryukov O.V. [Processing Stations Automation Systems for Efficient Gas Transport]. Avtomatizatsiya v Promyshlennocti [Automation in Industry], 2008, no. 6, pp. 6-10. (in Russ.)
5. Kryukov O.V. [Unified Monitoring and Control System of Electric Driven Gas Compressor Units]. Advanced Information Technology, Automation Tools and Systems and their Implementation at Russian Enterprises: MNPK Collected Papers, AITA-2011, Moscow, IPU RAN, 2011, pp. 329-350. (in Russ.)

6. Puzhaylo A.F. and others. [Energy-Saving and Automation of GM Compressor Stations Electrical Equipment]. O.V. Kryukov (ed.). N. Novgorod, Vector TiS, vol. 2, 2011.664 p. (in Russ.)

7. Kryukov O.V. Electric Drive Systems in Compressor Stations with Stochastic Disturbances. Russian Electrical Engineering, 2013, vol. 84, no. 3, pp. 135-140.

8. Kryukov O.V. Intelligent Electric Drives with IT Algorithms. Automation and Remote Control, 2013, vol. 74, no. 6, pp. 1043-1048.

9. Milov V.R., Shalashov I.V., Kryukov O.V. [Prediction and Decision-Making Procedures in Technical Equipment Maintenance]. Avtomatizatsiya v Promyshlennocti [Automation in Industry]. 2010, no. 8. C.47-49. (in Russ.)

10. Kryukov O.V. [Regression Invariant Algorithms of Electric Drives Control under Stochastic Disturbances]. Electricity, 2008, no. 9, pp. 45-51. (in Russ.)

11. Kryukov, O.V. [Embedded System of Diagnostics and Prediction of Asynchronous Electric Drives Operation]. Izvestiya VUZov [Proceedings of Institute of Higher Education]. Electromechanics, 2005, no. 6, pp. 43-46. (in Russ.)

12. Kryukov O.V. [Methodology and Tools of Neuro-Fuzzy Prediction of EGCU Condition]. Elektrotekhnika [Electrical Engineering], 2012, no. 9, pp. 52-57. (in Russ.)

13. Babichev S.A., Zakharov P.A., Kryukov O.V. [Monitoring of Driven Electric Motors Technical Condition of Gas Compressor Units]. Kontrol. Diagnostika. [Control. Diagnostics.] 2009, no. 7, pp. 33-39. (in Russ.)

14. Babichev S.A., Bychkov E.V., Kryukov O.V. Analysis of Technical Condition and Safety of GasPumping Units. Russian Electrical Engineering, 2010, vol. 81, no. 9, pp. 489-494.

15. Kryukov O.V., Stepanov S.E., Titov V.G. [Embedded Systems of Electric Motors Technical Condition Monitoring for Energy Safety of Gas Transport]. Energobezopastnost $i$ energosberezhenie [Energy Security and Energy-Saving], 2012, no. 2, pp. 5-10. (in Russ.)

16. Kryukov O.V., Repin D.G. [On-line Monitoring Systems of Power Plants for Energy Safety of Compressor Stations]. Gas Industry, 2014, no. 712, pp. 84-90. (in Russ.)

17. Babichev S.A., Zakharov P.A., Kryukov O.V. Automated Monitoring System for Drive Motors of Gas-Compressor Units. Automation and Remote Control. 2011, v. 72, no. 1, pp. 175-180. 
18. Babichev S.A., Kryukov O.V., Titov V.G. Automated Safety System for Electric Driving Gas Pumping Units. Russian Electrical Engineering. 2010, vol. 81, no. 12, pp. 649-655.

19. Kryukov O.V. Methodology and Tools for Neuro-Fuzzy Prediction of the Status of Electric Drives of Gas-Compressor Units. Russian Electrical Engineering, 2012, v. 83, no. 9, pp. 516-520.

20. Milov V.R., Suslov B.A., Kryukov O.V. Intelligent Management Decisions Support in Gas Industry. Automation and Remote Control, 2011, vol. 72 , no. 5 , pp. 1095-1101.

21. Kryukov O.V. [Intelligent Electric Drives with IT-Algorithms]. Automation in Industry, 2008, no. 6, pp. 36-39. (in Russ.)

22. Kryukov O.V., Serebryakov A.V. [DecisionMaking Method and System on Prediction of Electric Driven Gas Compressor Units Technical Condition]. Elektrotekhnicheskie Sistemy i Kompleksy [Electrical Systems and Complexes], 2015, no. 4 (29), pp. 35-38. (in Russ.)

23. Kryukov O.V., Serebryakov A.V. [Synthesis Methods of Embedded Systems of High Voltage Motors Technical Condition Prediction]. Sostoyanie $i$ perspectivy razvitiya elektro- $i$ teplotekhnologii [State and Development Prospects of Electrotechnics and Heat Technology] Materials of International Scientific and Technical Conference: XVIII Benardos Readings, Ivanovo, 2015, pp. 69-73. (in Russ.)

24. Babichev S.A., Zakharov P.A., Kryukov O.V. [Automated On-line Monitoring System of Gas Compressor Units Driven Motors]. Automation in Industry, 2009, no. 6, pp. 3-6. (in Russ.)

25. Babichev S.A., Bychkov E.V., Kryukov O.V. [Technical Condition and Safety Analysis of Electrical Driven Gas Compressor Units]. Elektrotekhnika [Electrical Engineering]. 2010, no. 9, pp. 30-36. (in Russ.)

26. Kadin S.N., Kazachenko A.P., Kryukov O.V., Reunov A.V. Questions Related to the Development of Metrological Assurance in the Design of Gazprom Facilities. Measurement Techniques, 2011, v. 54, no. 8, pp. 944-952.

27. Zakharov P.A., Kryukov O.V. [Monitoring and Prediction of UGS CS EGCU Technical Condition]. Gas Industry, 2013, no. 700, pp. 113-119. (in Russ.)

28. Babichev S.A., Kryukov O.V., Titov V.G. [Automated Safety System of Electric Driven Gas Compressor Units]. Elektrotekhnika [Electrical Engineering], 2010, no. 12, pp. 24-31. (in Russ.)

Received 4 February 2016

\title{
ИСКУССТВЕННЫЕ НЕЙРОННЫЕ СЕТИ ПРОГНОЗИРОВАНИЯ ТЕХНИЧЕСКОГО СОСТОЯНИЯ ЭЛЕКТРОДВИГАТЕЛЕЙ ГАЗОПЕРЕКАЧИВАЮЩИХ АГРЕГАТОВ
}

\author{
О.В. Крюков ${ }^{1}$, А.В. Серебряков ${ }^{2}$ \\ ${ }_{1}^{1}$ ОАО «Гипрогазцентр», г. Нижний Новгород, \\ ${ }^{2}$ Нижегородский государственный технический университет им. Р.Е. Алексеева, \\ г. Нижний Новгород
}

Рассмотрены вопросы проектирования эффективных и достоверных систем оперативной диагностики электродвигателей электроприводных компрессорных станций. Представлена статистика выхода из строя наиболее ответственных установок газотранспортных систем - электроприводных газоперекачивающих агрегатов. Разработана методология и архитектура искусственных нейронных сетей для получения прогнозных моделей электрических машин мегаваттного класса. Приведены примеры нейро-нечеткого прогнозирования технического состояния и ресурса статорных обмоток синхронных машин. Получены тесты селекционированных сетей, нечеткая модель Бокса - Дженкинса, модели метода анализа динамики спектральных составляющих, прогнозирование величин тока и температур статора. Сопоставительные результаты анализа ожидаемых состояний электрических машин магистрального транспорта газа, исходя из учета различных эксплуатационных факторов работы электроприводных газоперекачивающих агрегатов, позволили выработать рекомендации по применению метода искусственных нейронных сетей.

Ключевые слова:электроприводные компрессорные станщии, газоперекачивающий агрегат, электродвигатель мегаваттного класса, искусственные нейронные сети, тесты селекционированных сетей, моделипрогнозирования величин тока и температур статора. 


\section{Лumepamypa}

1. Пужайло, А.Ф. и др. Энергосбережение и автоматизация электрооборудования компрессорных станиий МГ: монография / А.Ф. Пужайло: под ред. О.В. Крюкова // Н.Новгород: Вектор ТиС. - 2010. - 570 с.

2. Крюков, О.В. Анализ и техническая реализаџия факторов энергоэффективности инновационных решений в электроприводных турбокомпрессорах / О.В. Крюков // Автоматизаџия в промышленности. 2010. - № 10. - C. 50-53.

3. Крюков, О.В. Пути модернизаџии электроприводных газоперекачивающих агрегатов / О.В. Крюков, С.Е. Степанов // Електромеханічні І енергозберігаючі системи. - 2012. - № 3 (19). - С. $209-212$.

4. Захаров, П.А. Системы автоматизачии технологических установок для эффективного транспорта газа / П.А. Захаров, Н.В. Киянов, О.В. Крюков // Автоматизация в промыиленности. - 2008. - № 6. C. 6-10.

5. Крюков, О.В. Комплексная система мониторинга и управления электроприводными газоперекачиваюшими агрегатами / О.В. Крюков // Труды МНПК «Передовые информачионные технологии, средства и системы автоматизации и их внедрение на российских предприятиях», АІТА-2011. - М.: ИПУ РАН. 2011.- C. 329-350.

6. Пужайло, А.Ф. и др. Энергосбережение и автоматизация электрооборудования компрессорных станций МГ: моногр. / А.Ф. Пужайло и др. ; под ред. О.В. Крюкова. -Н. Новгород, ВекторТиС, 2011. - Т. 2. $664 c$.

7. Kryukov, O.V. Electric drive systems in compressor stations with stochastic perturbations / O.V. Kryukov // Russian Electrical Engineering. - 2013. - T. 84, № 3. -C. 135-140.

8. Kryukov, O.V. Intelligent electric drives with IT algorithms / O.V. Kryukov // Automation and Remote Control. - 2013. - T. 74, № 6. - C. 1043-1048.

9. Милов, В.Р. Процедуры прогнозирования и принятия решений системе технического обслуживания и ремонта / В.Р. Милов, И.В. Шалашов, О.В. Крюков // Автоматизация в промышленности. - 2010. № 8. - C.47-49.

10. Крюков, О.В. Регрессионные алгоритмы инвариантного управления электроприводами при стохастических возмущениях / О.В. Крюков // Электричество. - 2008. - № 9. - C. 45-51.

11. Крюков, О.В. Встроенная система диагностирования и прогнозирования работы асинхронных электроприводов / О.В. Крюков // Известия вузов. Электромеханика. - 2005. - № 6. - С. 43-46.

12. Крюков, О.В. Методология и средства нейро-нечеткого прогнозирования состояния ЭГПА। О.В. Крюков // Электротехника. - 2012. - № 9. - С.52-57.

13. Бабичев, С.А. Мониторинг технического состояния приводных электродвигателей газоперекачивающих агрегатов / С.А. Бабичев, П.А. Захаров, О.В. Крюков // Контроль. Диагностика. - 2009. - № 7. - С. 33-39.

14. Babichev, S.A. Analysis of technical condition and safety of gas-pumping units / S.A. Babichev, E.V.Bychkov, O.V. Kryukov// Russian Electrical Engineering. - 2010. - T. 81, № 9. -C. 489-494.

15. Крюков, О.В. Встроенные системы мониторинга технического состояния электроприводов для энергетической безопасности транспорта газа / О.В. Крюков, С.Е. Степанов, В.Г. Титов // Энергобезопасность и энергосбережение. - 2012. - № 2. - С. 5-10.

16. Крюков, О.В. Системы оперативного мониторинга технического состояния энергоустановок для энергетической безопасности компрессорных станций / О.В. Крюков, Д.Г. Репин // Газовая промышленность. - 2014. - № 712. - C. 84-90.

17. Babichev, S.A. Automated monitoring system for drive motors of gas-compressor units / S.A. Babichev, P.A. Zakharov, O.V. Kryukov // Automation and Remote Control. - 2011. - T. 72, № 1. - C. 175-180.

18. Babichev, S.A., Automated safety system for electric driving gas pumping units / S.A. Babichev, O.V. Kryukov, V.G. Titov// Russian Electrical Engineering. - 2010. - T. 81, № 12. - C. 649-655.

19. Kryukov, O.V. Methodology and tools for neuro-fuzzy prediction of the status of electric drives of gascompressor units / O.V. Kryukov // Russian Electrical Engineering. - 2012. - T. 83, № 9. - C. 516-520.

20. Milov, V.R., Intellectual management decisions support in gas industry / V.R. Milov, B.A. Suslov, O.V. Kryukov// Automation and Remote Control. - 2011. - T. 72, № 5. - C. 1095-1101.

21. Крюков, О.В. Интеллектуальные электроприводы с IT-алгоритмами / О.В. Крюков // Автоматизация в промыишленности. - 2008. - № 6. - С. 36-39.

22. Крюков, О.В. Метод и система принятия решений по прогнозированию технического состояния электроприводных газоперекачивающих агрегатов / О.В. Крюков, А.В. Серебряков // Электротехнические системы и комплексы. - 2015. - № 4 (29). - С. 35-38.

23. Крюков, О.В. Методы синтеза встроенных систем прогнозирования технического состояния высоковольтных двигателей/ О.В. Крюков, А.В. Серебряков // Состояние и перспективы развития электро- и теплотехнологии: материаль междунар. науч.-техн. конф. (ХVIII Бенардосовские чтения). - Иваново, 2015. - C. 69-73 


\section{Электромеханические системы}

24. Бабичев, С.А. Автоматизированная система оперативного мониторинга приводных двигателей газоперекачивающих агрегатов / С.А. Бабичев, П.А. Захаров, О.В. Крюков // Автоматизация в промышиленности. - 2009. - № 6. - С. 3-6.

25. Бабичев, С.А. Анализ технического состояния и безопасности электроприводных газоперекачивающих агрегатов / С.А. Бабичев, Е.В. Бычков, О.В. Крюков // Электротехника. - 2010. - № 9. - С. 30-36.

26. Questions related to the development of metro-logical assurance in the design of Gazprom facilities / S.N. Kadin, A.P. Kazachenko, O.V. Kryukov, A.V. Reunov // Measurement Techniques. - 2011. - T. 54, № 8. C. $944-952$.

27. Захаров, П.А. Мониторинг и прогнозирование технического состояния ЭГПА КС ПХГ/ П.А. Захаров, О.В. Крюков // Газовая промьшиленность. - 2013. - № 700. - С. 113-119.

28. Бабичев, С.А. Автоматизированная система безопасности электроприводных газоперекачивающуих агрегатов / С.А. Бабичев, О.В. Крюков, В.Г. Титов // Электротехника. - 2010. - № 12. - C. $24-31$.

Крюков Олег Викторович, д-р техн. наук, доцент, главный специалист, АО «Гипрогазцентр», г. Нижний Новгород; o.kryukov@ggc.nnov.ru.

Серебряков Артем Владимирович, канд. техн. наук, доцент, Нижегородский государственный технический университет им. Р.Е. Алексеева, г. Нижний Новгород; serebryakov@ardman.ru.

Поступила в редакцию 4 февраля 20162.

\section{ОБРАЗЕЦ ЦИТИРОВАНИЯ}

Kryukov, O.V. Artificial neural networks of technical state prediction of gas compressor units electric motors / O.V. Kryukov, A.V. Serebryakov // Вестник ЮУрГУ. Серия «Энергетика». - 2016. - Т. 16, № 1. C. $66-74$. DOI: 10.14529 /power160110

\section{FOR CITATION}

Kryukov, O.V., Serebryakov A.V. Artificial Neural Networks of Technical State Prediction of Gas Compressor Units Electric Motors. Bulletin of the South Ural State University. Ser. Power Engineering, 2016, vol. 16, no. 1, pp. 66-74. DOI: $10.14529 /$ power160110 